\title{
KEEPING THE UNIFORM STATE LAWS UNIFORM
}

\author{
WILLIAM M. HARgEST
}

The subject of uniformity in laws seems to have caught the imagination of many people. It is a sort of shibboleth of the age. But uniformity can be overdone. The tendency of the unthinking and uninformed is to imagine that the panacea for most governmental ills is uniformity, and that the panacea for all diversity of law on any given subject is an act of Congress. Recently there have been frequent attempts to have Congress enter fields of legislation heretofore properly within the exclusive domain of the states. ${ }^{1}$ Many national business organizations believe that the remedy for the particular troubles that confront them in their several spheres of activity lies in uniformity and are endeavoring to frame and secure the adoption of uniform legislation, state and federal, affecting their particular interests. They, perhaps, like very many people, do not know that there is an organization, official in its nature, formed exclusively for the purpose of considering upon what subjects it is desirable to undertake uniformity in state legislation and of preparing with the utmost care uniform laws to be adopted by the several states upon those subjects approved by it. It is the National Conference of Commissioners on Uniform State Laws, which has been in existence since 1890 . Some of our best legislation, particularly on commercial subjects, has resulted from its labors, such as the Negotiable Instruments Act, the Uniform Warehouse Receipts Act, the Uniform Sales Act, and the Uniform Partnership Act. There are, of course, many others.

The late Simeon E. Baldwin, former Governor and Chief Justice of Connecticut, and once President of the American Bar Association, said that the example furnished by the Naticnal Conference of Commissioners on Uniform State Laws led to the formation of the Hague Conference. ${ }^{2}$ If that be true and the National Conference of Commissioners on Uniform State Laws

'Some phases of this tendency have been discussed by Hon. James M. Beck in "The Vanishing Rights of the States" (I926).

2 (I904) I7 HaRv. L. Rev. 400, 403. 
had accomplished nothing else, it would have abundantly justified its existence. However, the ignorance concerning this organization and its functions is colossal, even among lawyers, legislators and judges. It is often regarded, by those who ought to be better informed, as a committee or a section of the American Bar Association. This misconception arises because the Conference meets for a week immediately preceding the American Bar Association and at the same place, and it works with and is approved by the American Bar Association. The American Bar Association is, of course, a voluntary organization, whereas the National Conference of Commissioners on Uniform State Laws is an official association, composed of commissioners appointed under the authority of the various states, territories, the District of Columbia, Porto Rico and the Philippine Islands.

The work of the National Conference, in the express preparation of proposed statutes, is done with extreme care. When an individual or an organization suggests to the Conference that uniformity is desirable upon a particular subject, the stiggestion is referred to a committee to first determine whether the subject is one upon which uniformity in the laws of the several states should be undertaken. The report of that committee is then laid before the National Conference at an annual meeting. If the subject is considered a proper one for uniformity, the matter is referred either to a special or to a standing committee, which committee, often with the aid of an expert, examines the laws of the several states and sometimes of foreign countries, and reports a tentative draft of an Act to the Conference. The tentative draft is considered, section by section, sometimes consuming several days. It is then referred back to the committee and must be considered, section by section, at a second annual meeting of the National Conference. It often happens that the same statute is under consideration by a committee, and by the Conference itself, in this way, for three or four years. Great care is given not only to the subject matter, but to phraseology. The frailty of the human language is such, however, that notwithstanding the care with which these Acts are prepared, they sometimes are subject to more than one interpretation. 
How, then, can the uniform laws be kept uniform? The cnswer is, by the courts. It is one thing for the legislatures to pass uniform state laws and quite another thing to have them so interpreted and construed by the courts as to keep them uniform. The attention of the National Conference was long ago attracted to the fact that many of the courts failed to recognize the importance of a construction that would preserve uniformity, and that organization has been striving for some years to bring this matter forcefully to the attention of the judiciaries.

It is now well settled that where a statute has been copied from the laws of another state it is to be assumed that the legislature accepted the construction which was placed upon it by the courts of the state from which it was taken. This principle is now of universal application. Realizing that the courts often overlook it, the National Conference of Commissioners on Uniform State Laws endeavors to have it applied and somewhat extended. To that end the National Conference, about fifteen years ago, determined to insert a section in every act that was recommended by the Conference, as follows:

"This act shall be so interpreted and construed as to effectuate its general purpose to make uniform the law of those states which enact it."

Some of the courts recognized the importance of keeping the uniform acts uniform, even before this provision of the uniform statutes was brought to their attention. In ror 3 a New York court referred to the fact that shortly after the Negotiable Instruments Act was passed a number of decisions of the courts failed to recognize the change made in the prior law of that State, but that the later cases without expressly overruling the earlier decisions had recognized it. The Court said: ${ }^{3}$

"The desirability of uniformity in the laws of various states with reference to negotiable instruments is so obvious, and the legislative intent to harmonize our theretofore conflicting decisions with those of other jurisdictions is, to my mind, so clearly expressed, that full effect should be given thereto."

\footnotetext{
'Broderick \& Bascom Rope Co. v. McGrath, 8I Misc. I99, 142 N. Y. Supp. 497 (1913).
} 
Other courts, since the insertion of the provision above referred to, have gone so far as to regard a decision of another state construing a uniform law as obligatory rather than advisory. For example, the Supreme Court of Utah, after referring to the language of the statute above quoted, said: ${ }^{4}$

"If, therefore, the section of the Uniform Sales Act here in question has been construed by the court of last resort of any state in which the Uniform Sales Act is in force, then I conceive it to be the duty of this court to follow such construction in order to comply with the spirit and purpose of section $5^{18}$, supra, and to maintain the uniformity of the provisions of the Uniform Sales Act. It would be utterly futile for the legislatures of the several states to adopt uniform laws upon any subject if each court of the several states followed the notion of its members with regard to how a particular provision should be construed and applied."

And the Supreme Court of Vermont, referring to the above provision in its statute, said: ${ }^{5}$

"In view of this requirement, decisions of the highest courts in other states having such enactment, involving its interpretation or construction, are precedents of more than persuasive authority. Speaking generally, they are precedents by which we are more or less imperatively bound, in cases where similar questions are presented."

Notwithstanding the principle declared by these tribunals, which we conceive to be the correct one, the courts have rather consistently failed to preserve uniformity. There are two outstanding reasons for this failure. One is the tendency of courts to adhere to stare decisis, and the other the failure to even refer to the statute law of their own state which governs the principle in the case.

The first reason is illustrated in several Missouri decisions which involved the question of a restrictive endorsement of a negotiable instrument. The leading case of Bank of Indian Ter-

- Stewart v. Hansen, 62 Utah 28I, 218 Pac. 959 (1923).

- Ittna Chemical Co. v. Spaulding and Kimball Co., 98 Vt. 51, 126 At1. 582, 585 (Ig24). 
ritory $\because$. First National Bank, ${ }^{6}$ was decided before the Negotiable Instrumicits Act went into effect in that state. The Act plainly changed the law on the subject in Missouri. But in three cases ${ }^{7}$ decided subsequently the same ruling was made as in the leading case. In none of these cases was the language of the statute referred to or considered and the decision was simply placed upon the authority of the former decision. The courts of Arkansas, however, clearly iilustrate what would happen when there is a proper regard for the statute. In that state the case of Johnson $v$. Schnabaum, ${ }^{8}$ referring to a restrictive endorsement, was decided before the passage of the Act, which changed the state law on the subject. When the same question arose subsequently in First National Bank v. Brunk, ${ }^{9}$ the former decision was overruled because, as the Court said, "the opinion in this case was delivered prior to the passage of the Negotiable Instruments Act."

Referring to the other reason, namely, the failure of courts to cite the statutes of their own states, an astounding situation is disclosed. A recent authoritative and comprehensive survey ${ }^{10}$ of uniform law enforcement in the states which have adopted such legislation reveals the following significant facts:-the courts in states which have adopted the Uniform Sales Act, when deciding questions to which that $A c t$ applied, failed to even refer to the Act in 353 cases while 94I cases cited it; as to the Negotiable Instruments Act, ignored it in 689 cases and referred to it in I7I7 cases; as to the Uniform Warehouse Receipts Act, ignored it in 70 cases and mentioned it rog times; as to the Uniform Partnership Act, failed to refer to it in 59 cases and cited it in 78 cases; and as to the Uniform Bills of Lading Act, ignored it 12 times and mentioned it 85 times. And similarly in the matter of

' 109 Mo. App. 665, 83 S. W. 537 (I904).

"National Bank of Rolla v. National Bank, I54 Mo. App. 624, 125 S. W. 513 (I9I0); National Bank of Commerce v. Mechanics Bank, I46 Mo. App. 580, 127 S. W. 429 (1910); Citizens Trust Co. v. Ward, I95 Mo. App. 223, I90 S. W. 364 (1916).

${ }^{8} 86$ Ark. 82, 109 S. W. 1163 (1908).

' 170 Ark. 583, 280 S. W. 372 (1926). 1926).

${ }^{10}$ Edward Thompson Company, Uniform Laws Annotated (Supp. 
various other Uniform Acts, the same judicial disregard has obtained. However, it is worthy of note that in cases to which the Uniform Conditional Sales Act, the Uniform Limited Partnership Act and the Uniform Desertion and Non-support Act applied, the courts in no instance failed to cite the said Acts. If the courts continue thus to disregard the statutes complete uniformity is hopeless.

The National Conference of Commissioners did not rest its efforts to bring about uniformity of interpretation with the insertion of the provision referred to above. In 1920 a volume ${ }^{11}$ on uniform state laws was edited and published under its auspices in which were gathered the decisions on the various statutes up to that time, and which included a comprehensive table showing the section numbers of each uniform act compared with the section numbers of the corresponding acts as adopted in the various states, so that the courts might have ready reference thereto. And further, in 1923 the National Conference of Commissioners urged the publishers of annotated and selected cases and the editors of digests, whenever possible, in reporting cases that cited a uniform act, to cite the section of the original act, as well as the section number of the statute under interpretation. In that same year the Pennsylvania Commissioners addressed to the judges of the courts of that state a letter calling attention to both of the above-mentioned publications, ${ }^{12}$ so that the judges might have ready reference to the interpretation of the uniform laws in the other states.

For years the National Conference of Commissioners has had a standing committee on Uniformity of Judicial Decisions, which annually reported the decisions construing uniform state laws, noting those which cited the acts, and those which applied but did not cite them. This work, however, has been superseded by the annotated publication mentioned above, ${ }^{13}$ revised supplements to which are issued periodically.' This committee also made and reported to the Conference in 1925 a comprehensive

1 Cearles T. Terry, Uniforar State Laws in the Untted States (1920).

${ }^{12}$ Supra notes Io and Ir.

${ }^{13}$ Supra note ro. 
table which is printed in the Handbook of the Conference for that year, showing the section numbers of all the uniform acts adopted in the several states, compared with the section numbers of the original acts as recommended by the National Conference.

There is yet another way in which diversity is introduced into uniform statutes. Much of our great volume of legislation in this country is the result of efforts on the part of individuals or organizations to pass laws to change conditions where there is no extended demand for such change. Thus many laws are passed merely to meet local situations. So it sometimes happens that when a uniform statute is passed in some state, a successful effort is made by such an organized group to amend it in that state although there is no general demand for such change. Thereupon diversity is immediately introduced.

The only proper way to amend uniform statutes is to call the attention of the National Conference of Commissioners on Uniform State Laws to the need of amendment. That Conference, as experience in the past has shown, then considers the question in the same way that it considers an original Act.. When satisfied as the Conference sometimes is, that an amendment is desirable, it prepares such an amendment with care, and recommends it for adoption to the several states. An observance of this rule would also go a long way toward keeping the uniform statutes uniform.

If the ideal of complete uniformity of these laws is to be realized, in practice as well as in theory, the surest means to that end is the full and complete cooperation of both the courts and the various state legislatures. Let the courts recognize the legislative declaration that the statute is to be interpreted so as to keep it uniform, and apply the doctrine of the Utah and Vermont cases, quoted above, to the effect that the construction placed on a uniform statute by the court of another state is rather of binding force and authority than merely persuasive. And a legislature which has accepted the work of the National Conference on Uniform State Laws and passed a statute recommended by it for the very purpose of making the law uniform, should accept no amendment to that statute unless the amendment also comes from the same source. 